\title{
Disability in the Netherlands: another dutch disease?
}

Citation for published version (APA):

Muysken, J., \& Rutten, T. (2002). Disability in the Netherlands: another dutch disease? METEOR, Maastricht University School of Business and Economics. METEOR Research Memorandum No. 051 https://doi.org/10.26481/umamet.2002051

Document status and date:

Published: 01/01/2002

DOI:

10.26481/umamet.2002051

Document Version:

Publisher's PDF, also known as Version of record

\section{Please check the document version of this publication:}

- A submitted manuscript is the version of the article upon submission and before peer-review. There can be important differences between the submitted version and the official published version of record.

People interested in the research are advised to contact the author for the final version of the publication, or visit the DOI to the publisher's website.

- The final author version and the galley proof are versions of the publication after peer review.

- The final published version features the final layout of the paper including the volume, issue and page numbers.

Link to publication

\footnotetext{
General rights rights.

- You may freely distribute the URL identifying the publication in the public portal. please follow below link for the End User Agreement:

www.umlib.nl/taverne-license

Take down policy

If you believe that this document breaches copyright please contact us at:

repository@maastrichtuniversity.nl

providing details and we will investigate your claim.
}

Copyright and moral rights for the publications made accessible in the public portal are retained by the authors and/or other copyright owners and it is a condition of accessing publications that users recognise and abide by the legal requirements associated with these

- Users may download and print one copy of any publication from the public portal for the purpose of private study or research.

- You may not further distribute the material or use it for any profit-making activity or commercial gain

If the publication is distributed under the terms of Article $25 \mathrm{fa}$ of the Dutch Copyright Act, indicated by the "Taverne" license above, 


\title{
DISABILITY IN THE NETHERLANDS:
}

\author{
ANOTHER DUTCH DISEASE?
}

\author{
JOAN MUYSKEN \\ TIM RUTTEN
}

\author{
CofFEE - Europe \\ Maastricht University
}

October 2002

The Netherlands is well known for its high employment growth and corresponding low unemployment rate. At various occasions the so-called Dutch miracle has been applauded, together with the underlying 'Polder model'. A feature that initially was less recognised in the international debate, but has been a long-debated topic in the Netherlands, is the vast amount of persons in disability schemes. From the outset of the introduction of the first scheme (WAO) in 1969, disability in the Netherlands has exceeded unemployment and has been growing consistently to a level of over 900 thousand persons. This trend has occurred despite various countermeasures of the Dutch government. Even the major reforms in 1994 only caused a brief respite: after a decrease, the amount of disabled workers in the Dutch disability schemes started to grow again and has nearly reached one million. Hence when regarded in a European context, the incidence of disabled workers in the Netherlands is very high, although unemployment is very low.

The high amount of disabled workers, together with its persistence, poses a serious problem, in economic as well as social terms. The inability of the Dutch society to deal with it effectively makes us wonder whether we are observing another Dutch disease. From that perspective we analyse the development over time of disability in the Netherlands and the efforts to reduce its incidence. 
The Netherlands is well known for its high employment growth and corresponding low unemployment rate. At various occasions the so-called Dutch miracle has been applauded, together with the underlying 'Polder model' that reflects the consensusoriented institutional framework facilitating this high employment growth. ${ }^{1}$ Figure 1 shows the sharp decline in unemployment in the second half of the 1990s, which instigated international interest in the Polder model. However, the foundations for this development were already laid in the economic reforms in the early 1980s, symbolised by the Wassenaar Accord in 1982.

Figure $1 \quad$ Unemployment and disability (x1000 pers.), $1969-2000$

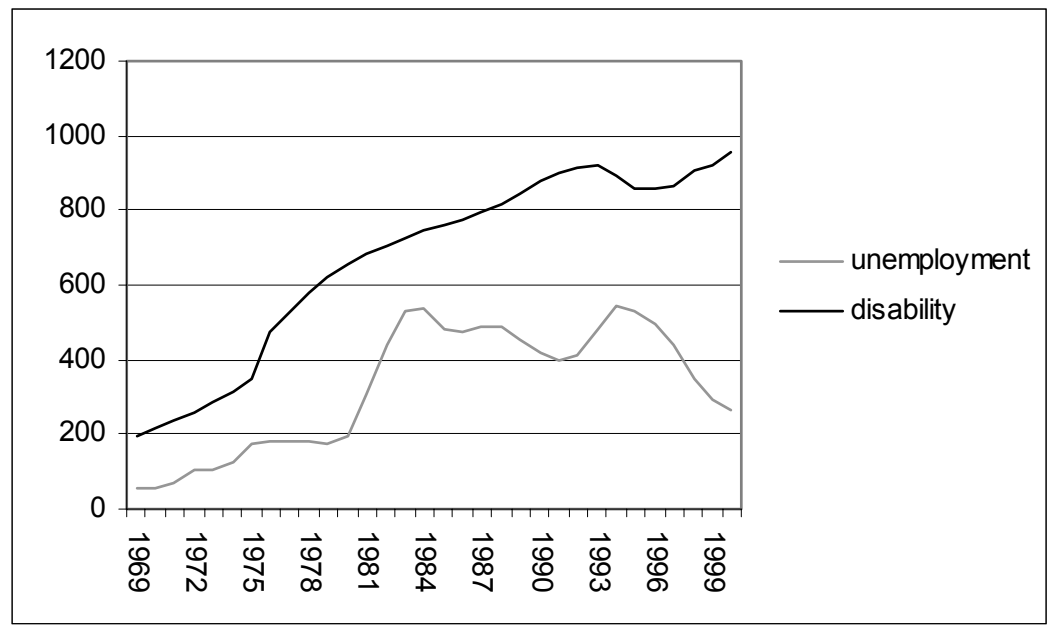

Source: LISV (2001)

A feature that initially was less recognised in the international debate, but has been a long-debated topic in the Netherlands, is the vast amount of persons in disability schemes. Figure 1 shows that from the outset of the introduction of the first scheme in 1969, the WAO, disability in the Netherlands has exceeded unemployment and has been growing consistently to a level of over 900 thousand persons. This trend has occurred despite various countermeasures of the Dutch government. Even the major reforms in 1994 only caused a brief respite: after a decrease, the amount of disabled workers in the Dutch disability schemes started to grow again and has nearly reached one million.

Figure 2 illustrates that when regarded in a European context, the incidence of disabled workers in the Netherlands is indeed very high, and unemployment is indeed very low. ${ }^{2}$ The figure shows the ratio of benefit recipients till age 65 for various categories (in man years ${ }^{3}$ ) related to the number of man years worked in a country the latter is an indication of earning capacity to pay for these benefits (NEI, 2002, Box $1.1)$.

An interesting observation is that Figure 2 suggests a trade-off between various categories of social security for various countries. While in the Netherlands

\footnotetext{
${ }^{1}$ A brief outline of the polder model, together with a critical review is given in OECD (2000) and Muysken (2001).

${ }^{2}$ The international comparison below is based on SER (2002).

${ }^{3}$ For instance, a woman who works part-time for 50 per cent, becomes disabled, and receives a benefit for $50 \%$, will count for 0.5 man-years. Also double counting of multiple recipients is avoided in this way. For further information see NEI (2002).
} 
disability is exceptionally high, this holds for unemployment in Belgium, old age and early retirement in France and social assistance in the UK and Denmark. From that perspective the Dutch overall position is among the best in Europe (Sociale Nota, 2001, p. 127).

Figure 2 Benefit-dependency ratios, 1998 (age till 65, in man years) ${ }^{4}$

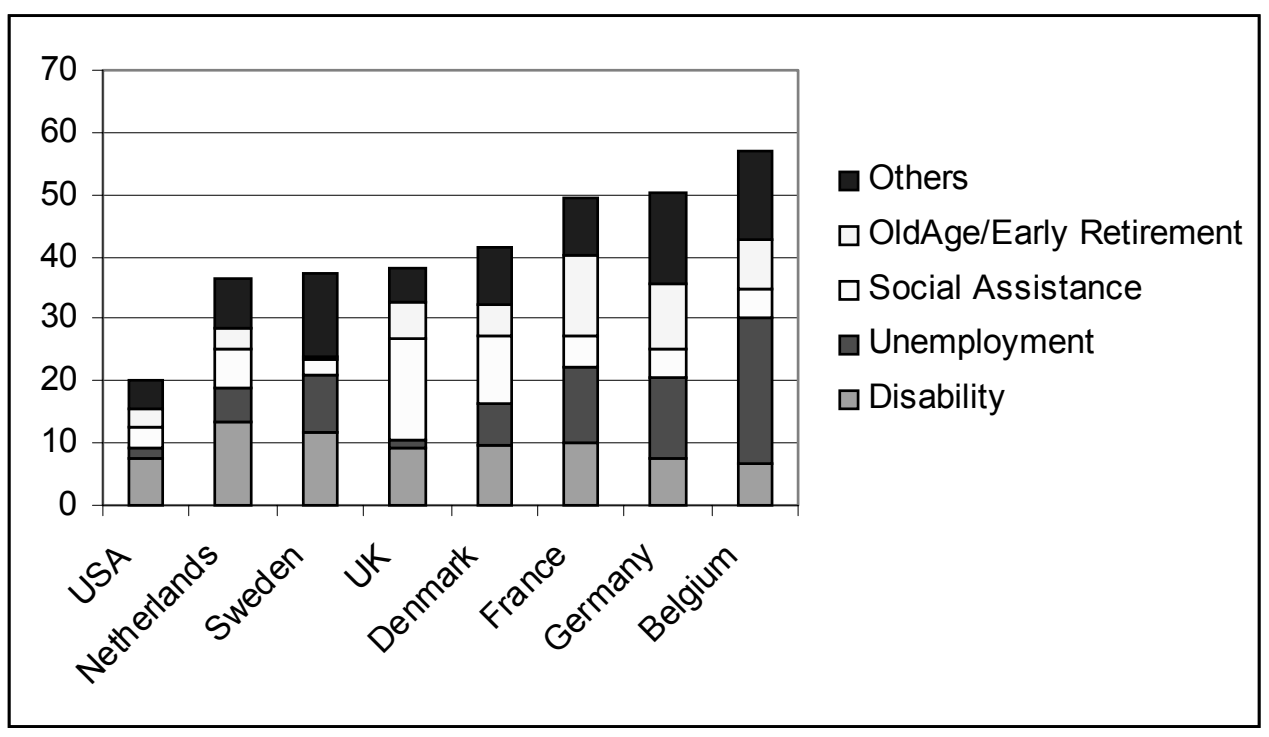

Source: SER (2002, Table 2.13), based on: NEI (2002), Sociale nota (2001).

Table 1 confirms the overall picture thus presented by Figure 2, since it shows that the Dutch employment rate is much higher than the EU-average in 2000. However, this only holds for the employment rate in persons. When corrected for the large incidence of part-time work in the Netherlands, the picture changes and the employment rate measured in man-years equals the EU-average. This implies that in terms of persons the position of the Netherlands in Figure 2 will be quite different, probably equal to the European average too. The incidence of disability measured in persons then is even more striking.

Table $1 \quad$ Employment rates in persons and man-years

\begin{tabular}{l|cc|cc}
\hline & \multicolumn{2}{|c|}{ The Netherlands } & \multicolumn{2}{c}{ EU average } \\
\hline & 1983 & 2000 & 1983 & 2000 \\
\hline Employment rate (pers.) & 50.6 & 72.1 & 60.1 & 64.2 \\
Part-time employment & & 32.5 & & 16.5 \\
Employment rate (man years) $^{\mathrm{a}}$ & & 57.3 & & 57.5 \\
\hline
\end{tabular}

Source: OECD (2002, Table 13, Figure 19)

${ }^{a}$ Calculated with part-time employment $37 \%$ of full-time employment hours (Dutch figure)

The high amount of disabled workers, together with its persistence - cf. Figure 1 poses a serious problem, in economic as well as social terms. And the inability of the Dutch society to deal with it effectively makes us wonder whether we are observing another Dutch disease. From that perspective we analyse the development over time of disability in the Netherlands and the efforts to reduce its incidence.

\footnotetext{
${ }^{4}$ The category "Others" includes sickness benefits and maternity leave. We included the contractual early retirement schedules for the Netherlands.
} 
Section 2 presents a brief overview of the disability laws in the Netherlands and puts them in an international perspective. Section 3 then starts the analysis of the development of disability over time by focussing on the flows in and out of disability. We find a remarkable difference between the flow behaviours of men and women, which leads to a focus on disability for women in section 4 . In the recent policy debates in the Netherlands special attention has been paid to the high incidence of disability of three distinct groups: young workers, subsidised workers and ethnic minorities. We consider these groups in sections 5-7, respectively. Section 8 evaluates the major reforms that will be implemented in 2003 and section 9 concludes.

\section{A short history of disability laws in the Netherlands}

The all-embracing disability law, Wet op de Arbeidsongeschiktheidsverzekering (WAO), was introduced on 1 July 1967. Its objective is to insure employees against income losses caused by long-lasting illness. The WAO replaced a number of existing disability and accident laws.

Figure $3 \quad$ Stacked composition of disability, $1969-2000$ (x1000 pers.)

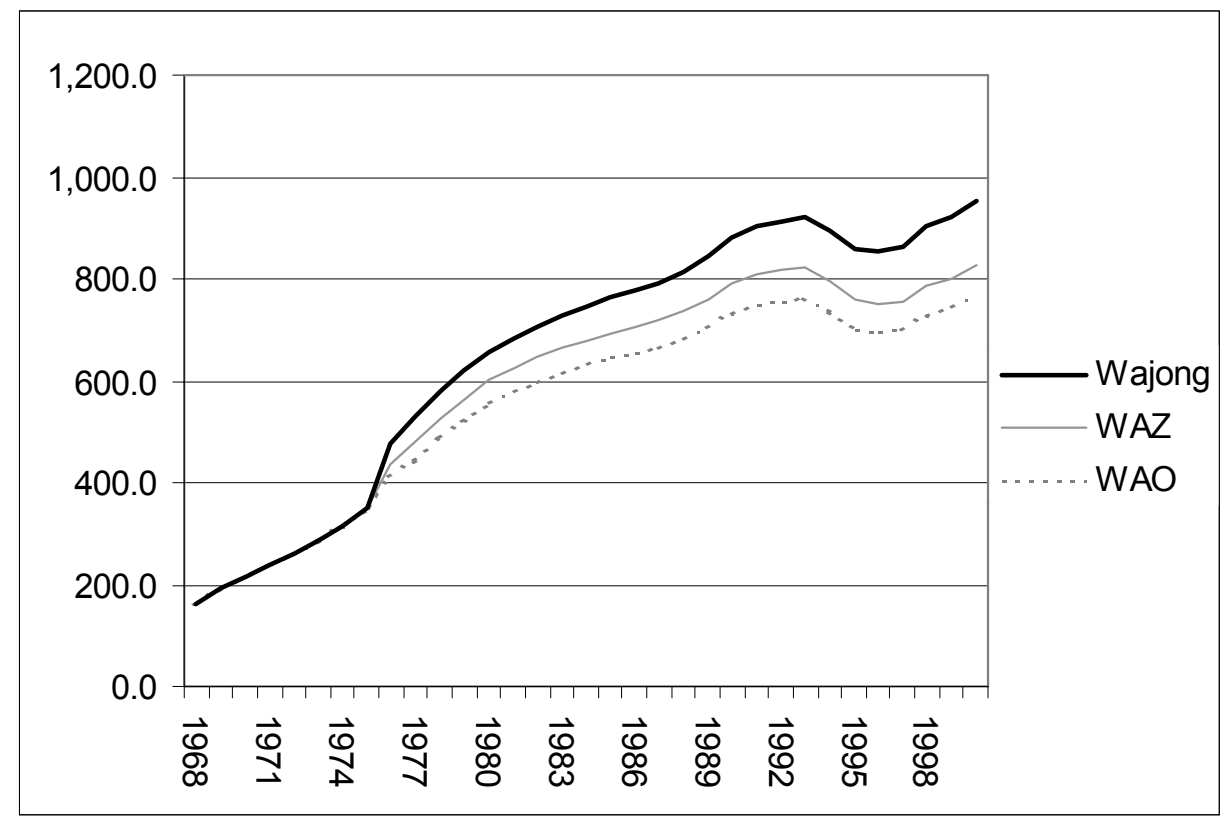

Source: LISV

On 1 October 1976, the WAO changed fundamentally due to the introduction of the Algemene Arbeidsongeschiktheidswet (AAW). The latter was an obligatory national insurance, whereas the WAO became supplementary. The AAW insured groups of people, most importantly self-employed and people disabled from an early age on, which had not been included before. From the introduction of the AAW onwards, AAW is only paid out if and to what extent it exceeds the WAO. The AAW was replaced by the Wet arbeidsongeschiktheidsvoorziening zelfstandigen (WAZ) and the Wet arbeidsongeschiktheidsvoorziening jonggehandicapten (Wajong) on 1 January 1998. Someone is called early disabled when he or she is disabled on the day of his or her $17^{\text {th }}$ birthday, or when he or she becomes disabled after this time and has studied at least six months in the year preceding. Figure 3 shows how in particular the 
Wajong is increasing in size. However, the main incidence of disability remains in the WAO.

From 1 January 1996 onwards, a major part of the conditions from the WAO has become valid for government personnel receiving a disability pension. Before this date, disabled government employees were part of a separate arrangement. The change was purely a formality.

\section{Reforms}

Over the years, several legal measures have been taken to reduce the number of disabled workers. Until 1 January 1987, someone who was partly disabled was eligible for full WAO benefits. The reasoning was that the opportunity to search new employment had decreased as a result of the disability. As a result, the unemployment component was included in the disability percentage. From 1 January 1987 onwards, benefits are paid out according to the degree of disability.

The first of August 1993 marked the introduction of the Wet Terugdringing Beroep op de Arbeidsongeschiktheidsregelingen (Wet TBA). This law introduced sharper entrance criteria and a stricter application of the option to declare workers partially disabled. Those workers disabled and under 45 years old on 1 August 1993 were re-evaluated on the basis of the new criteria for disability.

As a consequence of all these reforms, expenditures on disability have been declining relative to GDP, as Figure 4 shows. Initially the expenditures declined because of a reduction in disability benefits and after 1993 also due to a reduction in the share of benefits. ${ }^{5}$ The decrease in the second half of the 1990s is also due to the strong growth in GDP (Donner, 2001, p. 25). However, Figure 4 underestimates the full disability expenditures since in many collective labour agreements (CAOs) the employer has agreed to pay additional benefits, on top of the legal benefits.

Figure $4 \quad$ Expenditures on disability in The Netherlands (\% GDP)

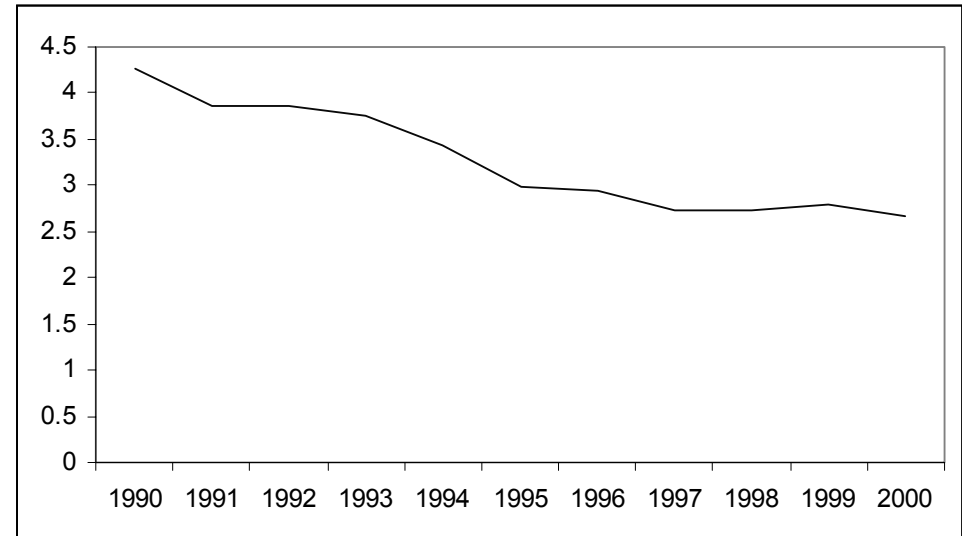

Source: SER (2002, Table 2.4)

\footnotetext{
${ }^{5}$ The benefits decreased during the 1980s from 80 per cent of the wage earned to 70 per cent. In the 1990s it further decreased to 70 per cent of the minimum wage - effectively the benefit was reduced by 28 per cent on average (Donner, 2001, p. 27).
} 


\section{International comparison}

In spite of all these reforms, there are still some distinctive features of the Dutch system, compared to other countries. In all countries one becomes eligible for disability payments after some period in a sickness scheme. In most countries, also the Netherlands, this period is one year. However, Table 2 shows that the differences in duration of obligatory sickness payments (in most cases up to $100 \%$ of the wage) are considerable; the same holds for the average contractual payments after 6 months. The Netherlands has a very generous sickness scheme, but the disability payments are relatively low, at least for the work-related disability (risque professionel). A striking difference with other countries is that no distinction is made - as a matter of principle - between work-related disability and disability due to other causes (risque social). The benefits for the latter category are rather generous compared to international standards.

According to Donner (2001, pp. $36 \mathrm{ff}$ ) five other remarkable features of the Dutch system are (1) partial disability is acknowledged, also below 50 per cent; (2) the degree of disability is based on earning capacity instead of working capacity; ${ }^{6}$ (3) a rather generous admission to the disability scheme, based on the lack of objective criteria to establish disability - many countries have a list of work-related illness and a strong separation in the involved medical profession between diagnoses and treatment; $^{7}$ (4) opposed to the permissive admission in disability, a very rigid protection exists towards firing a sick worker according to international standards: this is only possible after two years - and therefore there are strong incentives towards disability schemes; (5) efforts for re-integration of disabled persons are low. ${ }^{8}$ All these features enhance a higher incidence of disability. It therefore is not surprising that a major reform, which was initiated in 2001 and will be formalised in 2002, addresses these issues. We elaborate this in section 8 .

Table 2 Duration and payment of illness and disability schemes, 1999

\begin{tabular}{l|lll|ll}
\hline & Sickness & & & \multicolumn{2}{l}{ Disability payment } \\
\hline & payment & duration & $\begin{array}{l}\text { Contractual } \\
\text { payment after } \\
6 \text { months }\end{array}$ & $\begin{array}{l}\text { Risque } \\
\text { social }\end{array}$ & $\begin{array}{l}\text { Risque } \\
\text { professionnel }\end{array}$ \\
\hline Belgium & 100 & 4 & 60 & 40 & 100 \\
Denmark & 100 & 2 & $80-100$ & 40 & 80 \\
Germany & 100 & 6 & 70 & var & 66,7 \\
France & $66,7-100$ & 12 & 70 & 50 & 100 \\
Netherlands & 100 & 52 & 100 & 70 & 70 \\
UK & 100 & 28 & & $66,75 £ /$ week & $108,1 £ /$ week \\
Sweden & 85 & 2 & $80-90$ & var & 100 \\
\hline
\end{tabular}

Source: SER (2002, Tables $2.14-15)$, var = variable scheme

\footnotetext{
${ }^{6}$ A person who gets a disability who would enable to function only at a level of minimum wage function will be disabled for $65 \%$ when the initial wage was 2.9 times the minimum wage, for $33 \%$ when 1.5 the minimum wage was earned and $0 \%$ when 1.18 the minimum wage was earned (Donner, 2001, p. 47).

${ }^{7}$ Due to this strong separation treatment is more directed towards cure and not to rebuild earning capacity. Moreover, since the physician involved in diagnosis is not involved in the treatment of the patient, information will be limited.

${ }^{8}$ The Netherlands has very low expenditures on vocational rehabilitation for disabled, when compared to other countries (Donner, 2001, p. 38). However, expenditures for active as well as passive labour market policies are relatively high (Sociale Nota 2002, p. 166).
} 
To analyse the development over disability over time further, we look at the flows to and from disability. Figure 5 shows some interesting phenomena in that respect.

Figure $5 \quad$ Inflow and outflow in disability (x1000 pers.), $1968-2000$

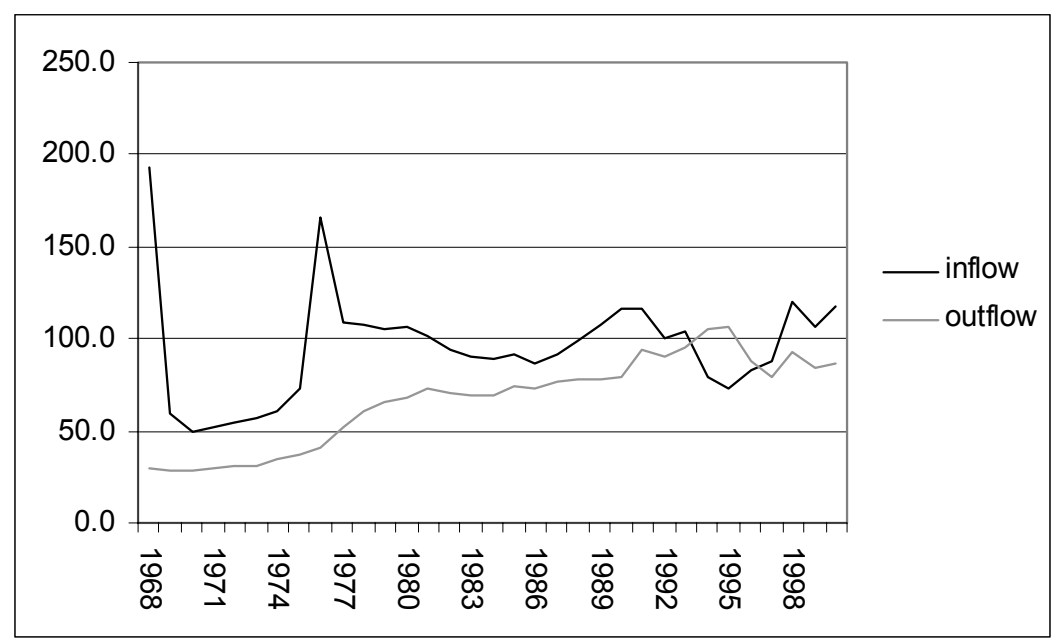

Source: LISV

Outflow increases steadily from 30,000 persons in 1968 till over 100,000 in 1995, after which there is a sudden decrease due to stringent reappraisals in line with the 1994 reforms (Aarts en De Jong, 1999). However, the effect is only short-lived; after 1997 outflow remains stable around 90,000 persons, at least till 2002. Inflow is marked by two peaks, in 1968 after the introduction of the WAO and in 1976, when the AAW is added - cf. the short history above. ${ }^{9}$ Apart from that, it is remarkably stable from 1977 onwards, around a level of 100,000, although here also the 1994 reforms left a brief imprint. ${ }^{10}$ Figure 5 shows that inflow has exceeded outflow by far over the whole period, except in 1993 - 1996, which is one way of explaining that disability has increased systematically, from just below 200 thousand persons in 1968 till almost one million in 2000.

Figure 6 gives a more detailed analysis by presenting the rate of inflow relative to the working population and the rate of outflow relative to the amount of disabled persons, while distinguishing between men and women. With respect to inflow, the difference between men and women is striking. After the surge in 1976, the inflow rate is decreasing consistently for men till a level just above 1 per cent. For women it fluctuates around a level of 2 per cent - since the last decade it is almost 1 percentage point higher than that for men. The increasing participation rate of women, together with the stable inflow rate of women, therefore explains why inflow in disability has remained stable in terms of persons (albeit fluctuating) as we observed in Figure 5 above, in spite of the decrease in the male inflow rate.

\footnotetext{
${ }^{9}$ It can hardly be accidental that the introduction of the WAZ and the Wajong in 1976 and the subsequent peak in the inflow in disability occurred not long after the oil crisis of 1973. In those times, employers and employees had a lot of control over the disability schemes. Since disability benefits generally exceed unemployment benefits, superfluous workers were guided in the latter schemes (Aarts en De Jong, 1999).

${ }^{10}$ The increase in 1996 may partly be explained by the inclusion of government workers in the WAO from 1996 onwards. This amounted to an initial increase of 16500 (Aarts en De Jong, 1999). But that cannot explain the fact that the increase persists the years after.
} 

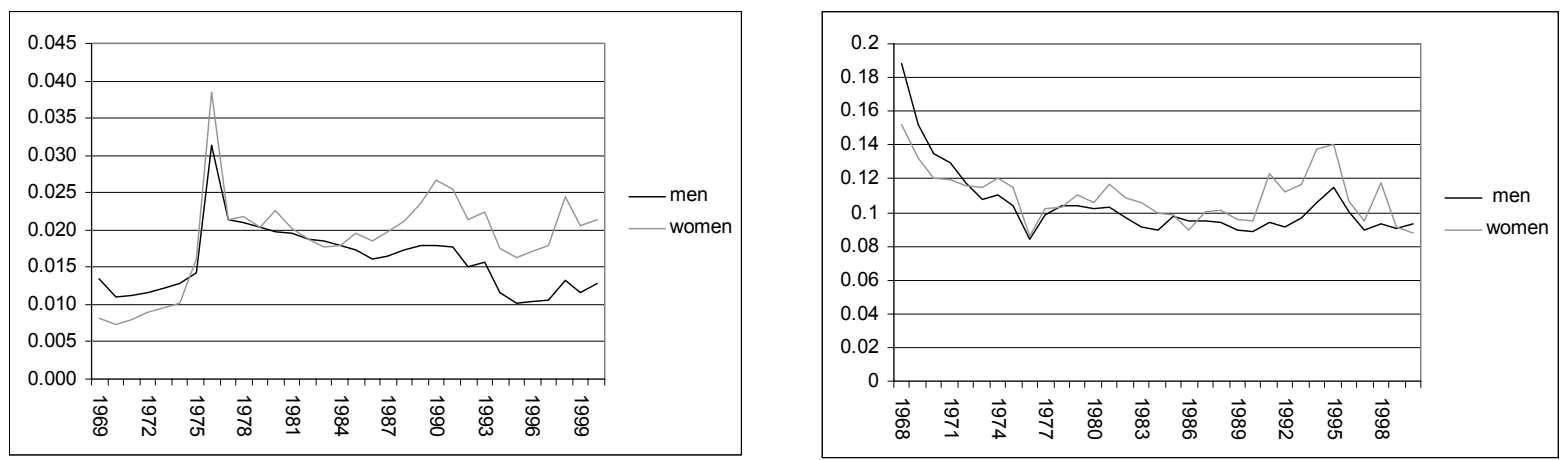

Source: LISV

The outflow rates of men and women are quite similar, although the outflow rate of women is somewhat higher. From 1977 onwards the outflow rate of men is remarkably stable, just below 10 per cent, while that for women fluctuates somewhat more, around a rate just above 10 per cent. Again the secular increase in outflow in terms of persons, at least till 1995, observed in Figure 5 is due to the increased participation of women.

An important observation is that although about two-thirds of the disability benefits go to men and women who are 45 years or older, over half of the inflow in disability stems from persons under 45 years of age (SER, 2002, p. 53). Whereas this inflow was reduced after the reform in the mid-nineties, more recently it increased again. This is reflected in the number of disabled persons in the age category of $25-$ 44 years, which decreased from 215,000 persons in 1990 to 163,000 in 1996, but then increased again to 205,000 persons in 2000. The most frequent diagnoses indicating disability in this group are mental problems and musculoskeletal disorders. ${ }^{11}$

People with lower education levels are still over-represented in the WAO scheme, but the differences in inflow between highly and less educated people have declined. In the building sector and manufacturing, the probabilities of becoming disabled have dropped sharply since 1980, whereas the risk has remained stable in the commercial services and has increased in the care sector (Donner, 2001, p.40). It is hardly surprising that workers in so-called flex jobs have a larger incidence to become disabled (SER, 2002, p. 63). The same holds for workers in large firms when compared to smaller firms (SER, 2002, p. 56; Donner, 2001, p. 40). However, Nyfer (2002) identified some large firms as best-practise organisations who were successful in eliminating disability by means of specific measures.

The above observations induce several questions, which we elaborate below. Why did the inflow rate of men decline, while that of women did not? Can we explain the strong fluctuations in both the inflow and the outflow rate of women? But there are also other aspects of disability that we should analyse further. For instance, Figure 3 shows the strong increase in early disabled persons. What happened there? Are there other groups who have a high incidence for disability? In policy debates both ethnic minority groups and persons in subsidised work have been mentioned.

\footnotetext{
${ }^{11}$ Around $40 \%$ of the inflow of the young age categories of both men and women is because of mental reasons (Van der Giezen and Geurts, 2001).
} 
Whereas the share of women in total employment increased from 25 per cent in 1976 to 40 per cent in 2000, the share of women in total disability increased from 24 per cent to 42 per cent - see also Table 3 . This is consistent with the higher inflow rate for women than for men observed in Figure 6.

Table 3 Men and women in disability schemes (x1000)

\begin{tabular}{c|ll|ll|ll}
\hline & \multicolumn{2}{|c|}{ WAO } & \multicolumn{3}{c|}{ WAJONG } & \multicolumn{2}{c}{ WAZ } \\
\hline & men & women & men & women & men & women \\
\hline 1976 & 320.9 & 94.5 & 21.4 & 19.4 & 17.4 & 0.8 \\
2000 & 446.8 & 333.9 & 61.7 & 50.0 & 35.7 & 15.7 \\
\hline Source: LISV
\end{tabular}

Source: LISV

As we have seen before, women also have a higher outflow probability than men. Whereas the outflow of men consists to a large extent of retirements, the outflow of women is mainly due to recovery - cf Figure 7. An interesting observation in this respect is that the outflow due to recovery for women remains higher relative to that of men, when it is taken into account that they are on average younger than men (Donner, 2001). Figure 7 also shows that the high fluctuations in outflow of women can for the largest part be attributed to the changes in outflow due to recovery. The 1996 reforms had strong impact in increasing outflow, but afterwards outflow dropped sharply.

Figure $7 \quad$ Outflow rates of men and women caused by recovery, $1968-2000$

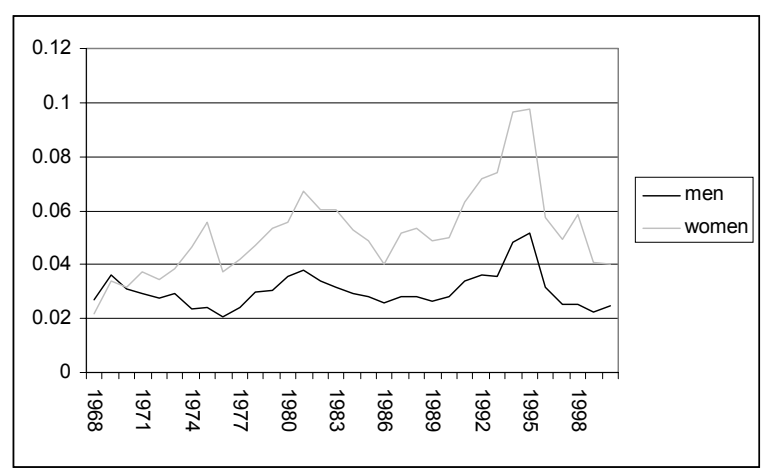

With respect to the higher inflow of women, several factors can be distinguished. According to Van der Giezen and Bruinsma (2000), the higher incidence of disability is partly caused by the fact that women are more often in jobs that are risky, and are more vulnerable to some labour market conditions than men. More specific, the inflow of women stems for over one third from the nursing and health care sector (which employs around 25 percent of all women), about 20 percent stems from the commercial services and 10 per cent is from retail services. Together, these sectoral differences explain half of the difference in disability incidence between men and women. ${ }^{12}$

\footnotetext{
${ }^{12}$ The difference in disability risk between men and women is highest in the commercial services, particularly the cleaning sector, and in the care sector. In these sectors women have $90 \%$ more likelihood to become disabled (Donner, 2001, p. 26).
} 
Another factor is that women are more susceptible to some labour market conditions than men. These conditions are a bad atmosphere at work, no fun in doing the job, and physical labour. This explains around $18 \%$ of the difference in disability risk between men and women (Van der Giezen and Bruinsma, 2000).

Contrary to popular thought, the pressure of the combination of work and family cannot explain the higher inflow rate of women: the presence of children in households consistently is found to have a mitigating impact on disability. ${ }^{13}$ However, for both young men and women, having children increases the probability of disability (Van der Giezen and Bruinsma, 2000).

\section{Young women}

Especially young women run a disproportionately large risk of ending up in disability schemes. However, the share of young women flowing into disability has not increased between 1991 and 1998: in both years, over 40 percent of the inflow of women into disability was younger than 35 years old. In contrast, the share of men of the same age category has decreased from 30 percent in 1991 to 21 percent in 1998 (Van der Giezen and Bruinsma, 2000).

The question then remains why young women run such a high risk to become disabled. The fact that women are more often in riskier jobs than men, and are more vulnerable to some labour market conditions, can only explain one-third of the difference between men and women in the younger age categories (Van der Giezen and Bruinsma, 2000). Care for children, the lack of a partner, and being main earner of the household are not relevant factors.

Part of the higher risk of (young) women to become disabled can be explained by pregnancies. Women who enter disability because of this, show low reintegration. The problem might be explained by the fact that the pregnancy leave and any possible subsequent period of illness are automatically included in the year of illness (Van der Giezen and Geurts, 2001).

\section{Mental disability}

In general, women are more often disabled on mental grounds than men - cf. Table $4 .{ }^{14}$ Perhaps as a result of this, women generally have a higher degree of disability than men - cf. Figure $8 .^{15}$ Around 15 percent of both men and women was suffering from burn-out complaints in 2000. However, absenteeism among women was higher than among men. While women generally have less autonomy and fewer possibilities to grow in their jobs, that leads only to a limited extent towards a higher disability risk. The relation between the mental work-pressure and sick leave is even weaker for women than for men. Hence, the mental work-pressure cannot explain the higher inflow rate of women into disability (Otten, Smulders and Andries, 2002). The only factor that is clearly related to absenteeism that has mental grounds is the institutional living pattern. Women with a partner but without children are significantly more prone to fall ill. Moreover, this pattern causes more than twice as many burnout complaints for women than for men. (Otten, Smulders and Andries, 2002).

\footnotetext{
${ }^{13}$ Van der Giezen and Bruinsma (2000). The presence of young children has an equally positive impact for men and women, however - van der Giezen and Geurts, 2001.

${ }^{14}$ This phenomenon is also observed in other countries (Donner, 2001, p. 36).

${ }^{15}$ About 25 per cent of disabled workers still does some paid work - Bruinsma en de Jongh, 2000.
} 
Table 4 Share of disability diagnosed on mental grounds

\begin{tabular}{lcc}
\hline & Men & Women \\
\hline 1991 & 34.3 & 48.9 \\
1997 & 36.6 & 50.3 \\
\hline
\end{tabular}

Figure 8 Share of partly disabled persons

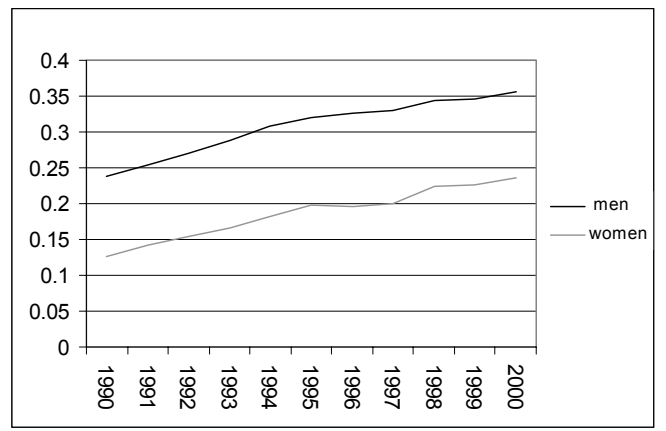

Source: LISV

Van der Giezen and Geurts (2001) suggest that women have a different work orientation than men; women may find work less self-evident than men do and may be less motivated to return to the labour market. Another suggestion by the same authors is that reintegration efforts are less effective for women for a number of reasons. One is that a larger proportion of women works part-time and may is not as rewarding to reintegrate part-time employees as it is to reintegrate full-time employees. Furthermore, employers may not consider a partial return to work practical for some jobs. Once again, the evidence is mixed and not very strong.

All in all the answer to the question why women have a larger incidence to become disabled is rather diffuse: there is a multitude of possible causes.

\section{$5 \quad$ Early disabled (Wajong)}

The introduction of the AAW in 1976 meant that from that moment onwards, early disabled who had not worked yet were included in the disability laws. Figure 3 above shows how the number of persons in Wajong increased from 40,000 in 1976 to about 127,000 persons nowadays - see also Table 5 .

Since 1976 the relative amount disabled under young men (under 36) has increased towards $6.3 \%$ of total disabled. For young women the picture is even worse (7.4\% of total disabled). Except for the years 1994 and 1995, the growth of disabled was higher than the growth of the relevant labour force (Aarts and De Jong, 1999). The increase was totally due to an increase of the amount of early disabled (Wajong); the amount of other disabled in that age category is declining (Van der Zouw, 1999).

As a consequence, nowadays about half of the total disabled workers under 36 is part of the Wajong scheme. In other words, half of the disabled younger than 36 has never had a regular job and has never gone through the year of illness (Aarts and De Jong, 1999). Moreover, of the persons in Wajong, 98 percent is disabled to the full extent and more than half of the persons in Wajong live in an institution (Van der Zouw, 1999). ${ }^{16}$

\footnotetext{
${ }^{16}$ Despite the high percentage of full disability, $18 \%$ of the early disabled had work through the Wet Sociale Werkvoorziening (WSW) in 1998 (Van der Zouw, 1999).
} 


\begin{tabular}{lcccccc}
\hline & 1990 & 1992 & 1994 & 1996 & 1998 & 2000 \\
\hline Persons (x1000) & 90.5 & 95.1 & 99.8 & 104.7 & 118.2 & 127.4 \\
Share in tot disability & 10.27 & 10.42 & 11.16 & 12.24 & 13.06 & 13.37 \\
Outflow rate & 1.83 & 1.96 & 2.21 & 2.67 & 4.29 & 3.76 \\
\hline Source: LISV & & & & & &
\end{tabular}

The increased amount of people in the Wajong is partly determined by demographic factors. The right to Wajong benefits was created in 1976. It is applicable when a person is 18 and ends at 65. As a result, the structural level of participants in Wajong has not been reached yet (Van der Zouw, 1999). The outflow from the Wajong is very low as table 5 shows. When the current inflow rate is maintained, the amount of early disabled would grow to almost 230,000 (Aarts and De Jong, 1999a). This amount is reached when the inflow and outflow probabilities remain at their current levels. The absolute growth is remarkable since the relevant part of the population (15 to 25 years old) has declined with 19\% between 1990 and 1998 (Aarts and De Jong, 1999a).

Around 7.5 percent of people with Wajong status are in the group "disabled from birth". Besides the fact that the categories may be overlapping and that people in the category "other" may have been disabled from birth, this at least indicates that people become (labelled) early disabled in the course of their lives. By far the greatest groups in the Wajong scheme are "mental disorders" (54 percent) and "exact problem is not known or not sufficiently diagnosed" (12 percent) (Aarts and De Jong, 1999).

An interesting observation is that early disabled spontaneously report for labour mediation more frequently than other groups. This indicates that early disabled have a relatively strong motivation to find a job if possible. Early disabled make use of reintegration instruments relatively often (Van der Zouw, 1999).

In short, the amount of disabled in Wajong has continuously grown since 1976. Although the absolute amount is still low relative to the WAO, it is very high when you imagine that Wajong is a very specialised law and that the severity of disability is in most cases very high.

\section{$6 \quad$ Subsidised work}

Recently, some policy makers have expressed the idea that subsidised employment creates a significant inflow of disabled workers. Dutch labour market policies have been focused in recent years on the creation of additional employment through subsidised jobs. Several variants of subsidised employment have been introduced. The Melkertbaan came to existence in 1995 in order to employ long-term unemployed. This kind of job was later replaced by the $I D$ and $W I W$ jobs for long-term unemployed and new entrants to the labour market, respectively.

Progressive expansion of direct job creation through three main programmes, ${ }^{17}$ resulted in a total number of participants of around 150,000 in 1999. Reflecting the different aims of these programmes, outflows to the normal labour market varied greatly in 1999: from 21 percent for jobs providing young people with job experience

\footnotetext{
${ }^{17}$ Next to WIW and ID, we also have WSW jobs, created for partially disabled persons.
} 
(WIW-jobs) to less than 1 percent for jobs for partially-disabled persons (WSW-jobs) (OECD, 2002).

Absence due to illness is indeed high in subsidised jobs: in 1999, the average absence (excluding pregnancy) was fifteen percent, with peaks of thirty percent - and the average length is substantial (Castenmiller et al, 2001). As a result, the inflow from $W I W$ organisations into the WAO is relatively high. Donner (2001, p. 28) indicates an inflow probability to the WAO of $2.04 \%$, which is the second highest of the branches compared. From the total outflow from $W I W$ jobs, five to six percent of workers end up in WAO.

In $I D$ jobs, sick leave is also relatively high. Outflow percentages of $I D$ jobs are lower than those of $W I W$ jobs, but the difference can mainly be explained by the fact that some $W I W$ workers switch to $I D$ jobs. The outflow from $I D$ jobs to the WAO is therefore estimated to be similar to $W I W$ jobs.

Although the outflow of workers from subsidised labour schemes to disability schemes is relatively high, the absolute figures cannot explain the significantly grown number of disabled. With outflow rates in total of around fifteen percent and a share of 6 percent ending up in the WAO, this means that the yearly flow from subsidised work to the WAO is about 14,000 .

\section{$7 \quad$ Ethnic minorities}

Until recently, no data were available from social services with regard to ethnic minority groups, due to the sensitive nature of the topic. Therefore we can only partly shed light on disability among ethnic minority groups. Although the incidence of disability is definitely a more profound problem for ethnic minorities, the effect in absolute numbers cannot explain any major trend in disability.

Of the 925,000 disabled workers in the Netherlands, seven percent, or 67,000, can be labelled ethnic minorities. The majority $(60,000)$ are in the WAO. Almost twothirds of this group are originally from Turkey and Morocco. This group is (in contrast to other ethnic minority groups in the Netherlands) over-represented in the WAO - see also Table 6. For every hundred native Dutch participants in the labour force, there are nine disabled workers. For Turks, this figure is twenty and for the Moroccans almost sixteen (Verwey-Jonker, 1999).

Table $6 \quad$ Percentage of workers in disability in 1999

\begin{tabular}{l|c|c|c}
\hline & Native Dutch & Turkey & Morocco \\
\hline Men & 8.7 & 17.3 & 16.5 \\
$\geq 40$ years & 15.5 & 51.4 & 41.3 \\
Women & 9.2 & 26.2 & 13.6 \\
\hline
\end{tabular}

By far the greatest number of WAO recipients belongs to the older age categories (50 years and older). With persons from over 40 years old, one sees from Table 6 that the incidence is far higher for the Turkish and Moroccan group than for native Dutch people. This group does not, as is often assumed, mainly consist of guest workers who came to the Netherlands in the 1960s to do physical labour; the majority of those workers have already retired. 
The problem is not limited to men. As Table 6 shows, the incidence is also relatively higher for Moroccan women and for Turkish women. Within the Turkish group, women are even more over-represented than men. The problem also occurs with the younger Moroccans and with young women from both groups. Especially for the recent WAO benefits (under one year in WAO), the share of women and of the younger age categories is remarkably high.

Turkish and Moroccan recipients are significantly more often fully disabled than native Dutch recipients. Of Turkish and Moroccan women, 90 percent is fully disabled. There are a number of possible explanations for this. One is that Turks and Moroccans are on average less healthy. This may be caused by income differences or ethnic factors. A second explanation is that because of the way benefits are granted, people with a low income are often declared capable to work (less than $15 \%$ disabled) despite a disability because they can still get jobs consistent with their old income level. So, they are in theory not financially limited by the disability. Given that Turks and Moroccans work more frequently in low-income jobs, they have to have a significantly limiting disability in order to be officially declared disabled.

With regard to diagnosis, the degree of disability on mental grounds is on average comparable to native Dutch persons. However, Turkish and Moroccan women score significantly higher than average, and so do Turkish and Moroccan men who have recently entered the WAO scheme. Of Turkish women 44 percent ended up in WAO due to mental reasons, almost 10 percent above average. With recent cases (up to one year in WAO), the percentage is as much as 48 percent, compared to 35 percent on average. For Turkish and Moroccan men, the mental disabilities are lower than the average, but for recent cases, the number is significantly higher: 39 percent, compared to 31 percent on average.

Verwey-Jonker (1999) suggested several reasons why the share of Turkish and Moroccan workers is relatively high. The first reason is that the average education levels among ethnic minority groups are lower than the average. Since low education levels increase the risk of disability, this may lead to an over-representation of ethnic minorities in the WAO scheme. According to the Verwey-Jonker Institute, this phenomenon could explain 33 to 40 percent of the reported differences. For Turkish and Moroccan men, this is even estimated to be 40 to 50 percent.

Another issue is the economic sector in which the disabled workers were working. Turks and Moroccans relatively often work in sectors that have high disability risk. Around a quarter of all Turkish and Moroccan WAO recipients had been working in the following three sectors: casual work and job agencies, cleaning, and the sector of subsidised work (WIW and WSW). This is far less the case for native Dutch persons. Almost one third of Turkish and Moroccan women in the WAO scheme had been working in the cleaning sector or for job agencies. These sectors are known for high work pressure and poor working conditions.

\section{The 2002 reform of the WAO}

\section{International background}

More and more efforts are made to analyse the disability problem from an international perspective, in order to have a proper background for reform proposals. The most influential report with respect to the reforms is Donner (2001). 
The report signals that various major developments in the Netherlands, most importantly the growing number of disabled women, back problems and mental problems, are also happening abroad (Donner, 2001, p. 49). ${ }^{18}$ However, the share of mental disorders in the Netherlands is still high and may be underestimated given the fact that in recent years part of the inflow was registered as unknown or received a temporary label (Sociale Nota 2001, 129)

As we mentioned above, NEI (2002) analysed the benefit dependency ratios up to 1999 for eleven countries: Austria, Belgium, Denmark, France, Germany, Great Britain, the Netherlands, Spain, Sweden, Japan and the US. Although benefit dependency of women has in general been gradually declining, the use by women of disability benefits has increased in several countries. In Belgium, more and more women make use of sickness benefits, disability benefits and maternity benefits. In Great-Britain, claims for disability and care benefits by women have increased, while the number of benefit years related to unemployment has decreased for both sexes, and survivor benefits have decreased for women. In the US, the share of sickness benefits for women has decreased, but the decrease coincided with a quite large increase in the number of disability benefits. In Spain, however, a sharp decrease of benefit dependency occurred after 1997, which was mainly caused by a decrease of disability benefits, especially for women.

Concerning age, NEI (2002) investigated benefit dependency ratios of four different age groups: younger than 55, 55-60, 60-65, and older than 65. In all countries, more than 40 percent of the ratio can be attributed to persons aged 65 and older. The Netherlands is the only country for which all four age-specific benefit dependency ratios in 1998 are at a lower level than they were in 1990. In contrast to the other countries, the Dutch age-specific ratios did not increase during the early $1990 \mathrm{~s}$, but instead remained fairly stable. This may indicate that some of the reforms have indeed been effective. The share of the youngest age category in benefit dependency is relatively high in the Netherlands. Although the benefit dependency of this category particularly has declined considerably since the mid-1990s, the Netherlands still stands out for its high inflow risks for employees under the age of 45. The difference between older people and younger people is smallest in the Netherlands, which has been the case since the beginning of the WAO history. The relatively steep increase of the WAO risks of young women also occurs in Germany and Sweden; however, there is no country where young women run such a higher risk than men as is the case in the Netherlands (Donner, 2001, p. 36).

Hence something in the Dutch system or mentality causes a relatively high probability of disability for women and young people, and a high incidence of mental disability.

\section{Problems with the system}

When one compares the Donner report with a second influential report on disability problems (SER, 2002), three main problems in the current system of disability benefits can de identified. ${ }^{19}$

\footnotetext{
${ }^{18}$ There is not much information about the amount of early disabled in other countries. The same holds for the difference in risks between small companies and large companies.

${ }^{19}$ In our view Donner concentrates too much on the first problem and pays too little attention to the other two problems.
} 


\section{1) The first year of illness does little to prevent disability.}

Since most experts agree that the first year of illness is crucial in preventing disability, it is especially worrisome that this threshold is not used to prevent disability. Although there are not many indications of active self-selection (fraud), passive selfselection may be an important reason for a high inflow as a result of the bad arrangements in the first year (Donner, 2001, p. 45). This may be caused by the following phenomena:

- The assessment is minimal and rather subjective, especially when it concerns mental disabilities. SER (2002, p. 64) mentions that over three recent years, the WAO admissions based solely on judgments made by one medical examiner increased to over one-third of the total. These evaluations result mainly in full disability judgements. Persons with mental complaints are relatively often solely evaluated by the medical examiner and relatively often receive full disability benefits.

- $\quad$ There is a strict division between diagnosis and possible reintegration measures (treatment), with more emphasis on diagnosis. The amount of timely evaluations decreased from $79 \%$ in 1998 to $63 \%$ in 1999 due to understaffing and administrative problems. Policy priorities are now set on a timely first WAO evaluation instead of reintegration and prevention to get rid of the backlog. As a result, there is no the time to check whether employer and employee are fulfilling their responsibility in the first year of illness to ensure reintegration. Another worrisome result of getting rid of the backlog is the occurrence of written reappraisals when people are admitted to the WAO, without being investigated in person by an official medical examiner (VerweyJonker, 1999; Donner, 2001, p. 54).

These factors lead to the conclusion of Donner that absence of a year or longer due to mental disability can be prevented by a different approach in many occasions (Donner, 2001, p. 45).

\section{2) The reintegration policies that are used are not reaching their target groups.}

The Back-to-work/IBO report estimated that 375,000 unemployed and partially disabled persons (some 5 percent of the labour force) are capable of returning to the active labour force within one year, provided they are assisted by an appropriate reintegration programme. ${ }^{20}$ The main findings of the report are:

- Education programmes are not very effective in reintegrating job seekers, especially when job seekers are not working at the same time.

- The reduction in non-wage labour costs through cuts in employers' social security contributions (SPAK) has a very limited contribution to the creation of employment at the lower end of the labour market.

- $\quad$ Almost two-thirds of social assistance beneficiaries are not obliged to actively look for work.

- $\quad$ Subsidised jobholders lack the incentive to find a regular job.

- The so-called "four-phase model" for assessing the distance of newly unemployed from the labour market, is quite inaccurate, and unnecessarily puts people in expensive schooling and training programmes.

- $\quad$ There are too many specific instruments that overlap each other.

\footnotetext{
${ }^{20}$ Cited in OECD (2002, p. 77).
} 


\begin{tabular}{l|ccccr}
\hline assessment stage & \multicolumn{4}{|c}{ reintegration (\%) } & \multirow{2}{*}{ total (abs.) } \\
\cline { 1 - 5 } & working & WW & track & none & 15684 \\
\hline $1^{\text {st }}$ claim & $54.8 \%$ & $3.8 \%$ & $17.3 \%$ & $24.1 \%$ & 35664 \\
$1^{\text {st }}$ year re-assessed & $52.1 \%$ & $4.5 \%$ & $8.9 \%$ & $34.5 \%$ & 44719 \\
other re-assessed & $29.5 \%$ & $2.5 \%$ & $3.4 \%$ & $64.7 \%$ & 286380 \\
other & $22.8 \%$ & $3.2 \%$ & $1.4 \%$ & $72.5 \%$ & 382447 \\
\hline total & $27.7 \%$ & $3.3 \%$ & $3.0 \%$ & $66.0 \%$ & \\
\hline
\end{tabular}

Source: GAK Nederland BV

Somewhat different conclusions are found in GAK (2001), who assert that only a limited portion of the WAO recipients is reached with the reintegration policies. Table 7 shows that out of a sample of almost 400,000 disabled persons only about 100,000 have been recently assessed whether they can be reintegrated or not. ${ }^{21}$ Only for the relatively new entrants a reintegration trajectory was instigated in about one-third of the cases, for the other 45,000 recently assessed persons such a trajectory was only started in about 5 percent of the cases. ${ }^{22}$ All in all, about 66 percent of the disabled persons in the sample is not even considered for reintegration.

Upon further inspection of this 66 percent (about 250,000 persons) only 9 percent was available for reintegration. For the total WAO population this might be about 5,000 persons - and consistent with the finding of the Back-to-work/IBO report the majority of these are partially disabled persons. GAK (2001) reckons that the amount of 5,000 might increase to at most 15,000 persons when strong pressure is applied to all disabled persons.

3) The target group is not motivated enough to return to work, possibly by the stigmatising effect of the WAO structure.

Motivation to return to work is low in the Netherlands. Disabled persons with physical complaints have a remarkably higher motivation to return to work than mental disabled persons (Ledeboer, 2001).

Donner (2001, p. 50) states that sick leave due to problems at work is generally accepted in the Netherlands. Subsequently, the disability process is initiated in which problems receive a medical label. The emphasis is very much on the fact that someone is ill and very little on tackling possible problems at work. In other words, compared to other countries, the Dutch disability scheme is very stigmatising.

Studies dealing with mental disability emphasise the importance of stigmatising effects. A large inter-state study in the USA ${ }^{23}$ indicated that that direct support to a 'disabled' worker can possibly be stigmatising and that believing that the supported employee needs an expert to provide support for his/her symptoms may actually hinder successful outcomes (ILO, 2000). Another study stated that the most

\footnotetext{
${ }^{21}$ Disabled persons are reassessed after one year and after 5 years.

${ }^{22} \mathrm{We}$ ignore here persons who are working or receiving unemployment benefits.

${ }^{23}$ The study featured 243 individuals in 10 programmes across 8 states, and utilised an 85-item questionnaire about individuals, disability information, employment features, employers and community connections. The findings included that staff support to a "disabled" employee on the job has a negative effect on work rate, work quality, co-worker relations and typical employment conditions (this is especially true when symptoms are present at work). Staff support to workplace personnel has a positive effect on work rate, work quality, co-worker relationships, typical employment conditions, and employee satisfaction.
} 
important obstacles identified by programme directors included self-deprecating attitudes, emotional instability, stigma, programmes not well adapted to the person's needs, and lack of recognition of the individual's potential (ILO, 2000, section 5.9). Both studies indicate that the effects of stigma on disability may be an important and underestimated factor.

Together the above problems indicate that the relatively high incidence of mental disability in the Netherlands may be caused by subjective evaluations, poor reintegration policies, and stigma resulting in low motivation to go back to work. The relatively high probability of disability for women and younger age categories may indirectly be explained by the same phenomenon; they may be more prone to mental disability and therefore end up in greater numbers in the disability scheme.

\section{Recommendations}

The plans of the government that started Summer 2002, to reform the WAO are mainly based on the recommendations made by Donner (2001). These are: ${ }^{24}$

- $\quad$ The disability scheme is restricted to totally and permanently disabled persons, with permanently but only partially disabled persons being covered by a private employers' insurance. The goal is to make the evaluation more medically objective. The strict division between diagnose and treatment is abandoned.

- $\quad$ The emphasis will shift from earning capacity to working capacity.

- $\quad$ Both employers and sick employees are required to take all the necessary measures to prevent, as much as possible, the latter from reaching the point of applying for a disability status. The goal is that possible conflicts are solved within the company, and an independent commission will be set up to mediate in cases that cannot be solved within the company. In other words, prevention is emphasised.

- $\quad$ Reintegration efforts are initiated already in the first year of sick leave before a person can apply for a disability status.

- It will be possible for an employer to fire an employee if he has done everything to reintegrate the employee.

\section{Comments $^{25}$}

While the risque social remains included in all proposals, a new element is the strict distinction between permanent and temporary disability. However, one should realise that this may be difficult to define operationally (CPB, 2001; OECD, 2002). Moreover, Donner proposes that periodical reassessments are removed since there will be strictly objective medical evaluations that only allow fully disabled persons in the WAO. But what about the growing number of mentally disabled workers, is there no chance of recovery? On the one side, Donner emphasises the fact that it's becoming increasingly difficult to set an objective norm for illness (Donner, 2001, page 44); on the other hand, the commission proposes a policy in which people are evaluated one time, which can only lead to a rejection or a full disability status,

\footnotetext{
${ }^{24}$ See also OECD (2002, p. 86).

${ }^{25}$ For a good overview of weak points in the proposal, cf. CPB (2001) and OECD (2002, p. 86).
} 
without reappraisals. We also think that a status of full disability is stigmatising and in itself excludes any hope of a return to the labour market.

What has hampered previous attempts to reform the WAO considerable is the failure to implement proposed reforms properly and their supervision. For instance, it is unclear how the emphasis should shift to prevention of sickness and how this independent committee should be set up and function (CPB, 2001). ${ }^{26}$ Also the report does not tackle the problem of the growing role of temporary work agencies in the transition of sick workers to the disability scheme (OECD, 2002).

An additional problem is that the proposals almost exclusively focus on the future inflow of disabled workers! The current stock of around one million disabled workers is largely disregarded (OECD, 2002). It seems hard to believe that the commission Donner has given up on all these people, especially considering all the evidence that a significant part is disabled unnecessarily.

It is questionable that the proposals make working financially more attractive relative to being inactive. $(\mathrm{CPB}, 2001$; OECD, 2002) In the same vein the introduction of a private scheme for partially disabled persons may lead to a relaxation of eligibility criteria and the topping-up of benefits. ${ }^{27}$ In that context it is interesting to note that employers and employees had agreed on a reform proposal wherein employers do no longer have to pay fines related to the incidence of disability in their firms and employees will receive a larger benefit when they become fully disabled. The intention of the current government not to honour that proposal created a lot of social unrest.

\section{Concluding remarks}

The dream of the former minister of social affairs Veldkamp has turned into a nightmare. In 1946 the catholic Veldkamp wrote a dissertation in which he roughly outlined the currently existing disability laws. These proposals were accepted unanimously in 1966 by both chambers of parliament - which is rather unique in the Dutch political history. However, in those days a strong climate of solidarity prevailed in Dutch society. (And natural gas was found which promised to be an unlimited source of income).

Things started already to turn sour after the second oil crisis, end 1979. In a tacit conspiracy employers and employees rid themselves of redundant workers by channelling them into disability: the WAO-heaven. The benefits were much higher than unemployment benefits, and other conditions were better too. These were also the days when the famous Wassenaar Accord was signed.

The number of benefit recipients increased steadily to around 1 million persons and has stabilised around that level ever since, in spite of the many efforts to reduce the disability incidence. In this paper we show how the composition of the disabled population changed from elder male persons in the late 1970s and early 1980s to women and later also young persons and ethnic minorities. Moreover, the incidence of mental disability increased strongly, to about half of the current inflow.

The efforts to reform the system in 1993 have not been very successful, and it took almost ten years before another effort was made to reform the system. In the good Dutch tradition the 1993 reforms went wrong because the implementation

\footnotetext{
${ }^{26}$ See also the radical reforms proposed by Nyfer (2001), which we mentioned above.

${ }^{27}$ This is the existing practice in many Collective Labour Agreements at this moment.
} 
remained a collective responsibility of employers and employees, with little individual incentives. It therefore is not surprising that the recent proposal of employers and employees to reform the system was to get rid of those incentives, that were gradually introduced over the past years. However, these partners provide no clear guarantees how the other proposed reforms-which roughly follow the Donner reforms-will lead to a strong reduction in disability. The newly appointed government in 2002 does not accept the proposed reduction in incentives and follows the Donnerreforms without this compensation. ${ }^{28}$

We think that the implementation of the new proposals will be very difficult without the cooperation of employers and employees. And the social unrest will hamper the decision making process - one should realise all persons affected by these laws represent about 10 percent of the voters. The Dutch disease in this context is that we need consensus for a good implementation of the system. But this consensus has been undermined by a systematic abuse of the system by employers, employees and society at large. Symptomatic for the latter is the remark by the current minister of social affairs, de Geus, who is responsible for the WAO. In a televised interview september 2002, he stated that given the large exploitation of the system, the number of persons in the WAO should be ruduced by $50 \%$ in a couple of years. Neither the interviewer, neither press reviews the next days commented on this.

The only solution for the disability problem in the Netherlands is a recognition of the abuse of the WAO and a change in the attitude towards work and working conditions. This requires a solution-oriented public debate, where creative measures are encouraged. Also responsibilities of the social partners should be clearly defined. For instance, Nyfer(2001) has made some interesting proposals. Firms should be made responsible for an active prevention and reintegration policy, if necessary through obligatory service contracts with professional institutions. Certification of these institutions then should be enacted, together with a systematic public evaluation of their performance. More flexible ways to use funds for reintegration of disabled workers should also be allowed. We hope that a consensus in this spirit can be found, leading to a cure of this typical Dutch disease.

\section{References}

Aarts, L. \& Ph. de Jong (1999), Het echte WAO-probleem, Economisch Statische Berichten, 19 March 1999, pp. 217-218

Aarts, L. \& Ph. de Jong (1999a), Het mysterie van de Wajong, Economisch Statische Berichten, 2 July 1999, pp. 512-513

Bruinsma, H. \& H. de Jongh (2000), Werkenden in de WAO, Economisch Statische Berichten, 25 February 2000, pp. 164-166

Castenmiller, P.G. et al (2001), Ziekteverzuim in de Wiw: Een onderzoek naar de opbouw van, de oorzaken van en het beleid ten aanzien van ziekteverzuim bij Wiw-instellingen, The Hague: Ministerie van Sociale Zaken en Werkgelegenheid

\footnotetext{
${ }^{28}$ Actually Donner was very instrumental in creating the agreement which forms the basis of the current government, and he has become minister of justice in that government.
} 
Donner (2001), Werk Maken Van Arbeidsgeschiktheid: Advies van de Adviescommissie Arbeidsongeschiktheid, Den Haag

Gak (2001), Bemiddelbaarheid van WAO-gerechtigden: Schattingen op basis van een steekproefonderzoek en een bestandsanalyse

Giezen, A.M. van der \& H. Bruinsma (2000), Vrouwen vaker in de WAO, Economisch Statische Berichten, 24 March 2002, pp. 248-250

Giezen, A.M. van der \& S.A.E. Geurts (2001), Feiten en ficties over vrouwen en de WAO, Economisch Statische Berichten, 22 June 2001, pp. 540-543

ILO (2000), Mental Health and Work: Impact, issues and good practices, International Labour Organization and World Health Organization, Geneva

LISV (2001), De WAO-beoordeling van 12-maandszieken, Bureau AS/tri

Muysken, J. (2001), The Dutch Polder Model: Will the Dykes Hold?, in E. Carlson and W.F. Mitchell (eds.), Achieving Full Employment, The Economics and Labour Relations Review, Supplement to Vol. 12, pp. 149-165

NEI (2002), Benefit dependency ratios: An analysis of nine European countries, Japan and the US, Final report, Rotterdam

Nyfer (2001), Enkeltje WAO: De gebrekkige begeleiding van werknemers met psychische klanten tijdens het eerste ziektejaar, Breukelen

OECD (2002), Economic Surveys 2001-2002: Netherlands, volume 2002/3, Paris

Otten, F., P. Smulders \& F. Andries (2002), Arbeidsuitval door burn-out, Economisch Statische Berichten, 4 January 2001, pp. 11-13

SER (2002), "Werken aan arbeidsgeschiktheid", Publicatienr. 5, 22 March 2002, pp. 44-70

Sociale Nota (2001), Ministerie van Sociale Zaken en Werkgelegenheid, SDU uitgevers, Den Haag

Sociale Nota (2002), Ministerie van Sociale Zaken en Werkgelegenheid, SDU uitgevers, Den Haag, pp. 160-168

TMP Worldwide (2001), Eindrapportage analyse WAO-bestand, SFB

Verwey-Jonker Instituut (1999), In de fuik van de WAO, Utrecht

Zouw, M. van der (1999), Het echte WAO-probleem: jonggehandicapten, Economisch Statische Berichten, 2 July 1999, pp. 510-512 